\title{
Sexual Capitalism: Marxist Reflections on Sexual Politics, Culture and Economy in the 21st Century
}

\author{
Paul Reynolds
}

\author{
Edge Hill University, UK, reynoldp@edgehill.ac.uk
}

\begin{abstract}
From an apparent impasse and crisis in the 1970s and 1980s - politically and intellectually - Marxism has recovered to offer critical insights into contemporary changes and developments in late capitalist societies. Sexuality has been one area where Marxist critiques of commodification and consumption, reification, cultural production and its hegemonic effects and the structures of feeling and meaning-making that compose contemporary subjectivities have been of significant value in decoding legal, political and cultural changes in the regulation, prohibition and propagation of forms of sex and sexuality. This discussion will draw from some of the most important contributions to Marxist critiques of sexuality, contemporary and historical, to outline the contours of a critique of contemporary sexuality in society, notably Peter Drucker, Holly Lewis, Rosemary Hennessy, David Evans, and Keith Floyd. The Marxist critique of contemporary sexual politics and rights claims both recognises the importance of these struggles and provides a materialist critique that demonstrates both the contemporary power of Marxist analysis and a critical engagement with queer and constructionist "orthodoxies". Marxism has become a central and important ground for exploring the vagaries of sexuality under capitalism in all its objectifying, commodifying, alienating and exploitative forms.
\end{abstract}

Keywords: sexuality, politics, culture, community, commodification, political economy

\section{Introduction}

Critical studies that focus on exploring sex and sexuality in contemporary societies are the site of a curious contradiction. Contemporary engagements with the history, politics and culture of sex and sexuality as socially constructed phenomena - which constitute what is now regarded as the "new sexuality studies" (Fischer and Seidman 2016) have emerged from avowedly post-Marxist, anti-Marxist or non-Marxist positions. Yet the key themes and issues that they raise are complementary to and extended by Marxist analyses. Despite this, Marxist analyses are very much marginalised, and a reader exploring the mainstream of critical literature on new sexuality studies might be forgiven for thinking Marxists have nothing to contribute. This might in part be a product of the failure, until recently, of Marxist and left parties and movements to prioritise sexuality as a focus for critical work and political engagement. For many of those who have fought for lesbian and gay legal recognition, equal treatment, rights, justice and policy change, the words of Edge (1995, 3-4) might still have resonance ${ }^{1}$ :

[...] the Marxist tradition has no more influence on the modern lesbian and gay movement than it deserves. Gay Marxists who are encouraged by their straight comrades and leaders to shun the very real gains won since the GLF by an autonomous lesbian and gay movement are being seduced into an essentially heterosexist project where gay issues are sidelined.

\footnotetext{
${ }^{1}$ But see Wolf (2009) on the myth of Marxist homophobia.
} 
More, left parties and movements influenced by Marxist theory and politics have been slow, until relatively recently, to take on the implications of a politics of sexuality and difference (the "Comrade Delta" crisis of the Socialist Workers Party being the most pronounced but by no means first example of the consequences of this neglect). ${ }^{2}$ This does not, however, imply that Marxism has limited relevance in deconstructing contemporary sexual capitalism, particularly in the context of contemporary sexual politics in North America and Europe, where the slow rolling out of legal recognitions and formal equalities seem to have brought about a sense of impasse or exhaustion to radical agendas. ${ }^{3}$ For example, contemporary characterisations of homonormativity signify a particular legitimacy of non-heterosexual sexualities that might be better seen as an expression of a changing hegemonic regime to incorporate difference and subdue opposition (see Duggan 2002; 2004). Duggan $(2002,179)$ identifies homonormativity as:

[...] a politics that does not contest dominant heteronormative assumptions and institutions, but upholds and sustains them, while promising the possibility of a demobilized gay constituency and a privatized, depoliticized gay culture anchored in domesticity and consumption.

As Pilkey et al. $(2017,152)$ observe of Lisa Duggan's critique: "homonormativity is not simply read as the neo-liberal and assimilative dimension of lesbian and gay rights claims but is an apolitical outcome firmly situated - 'anchored', as Duggan puts it - in the domestic sphere".

The celebration of the 200th anniversary of Marx's birth is a suitable point not only to reflect on the areas where Marx's political economy has so clearly influenced world affairs and intellectual understandings of social life; it is also important to explore where Marxism has made a less visible but nevertheless critical contribution. This brief discussion seeks to locate the importance of Marxist insights based upon a materialist political economy and an appreciation of the class nature of social division and conflict in understanding and theorising contemporary sexual politics.

The second section will briefly digest the contribution of Marxism to understanding sexuality and sexual politics. The third section will outline key contemporary analyses and their thematic critiques of commodification, identity recognition, reification and the cultural production of sexual hegemony in deconstructing sexual politics.

\section{Locating Marxism within Sexual Critiques}

The emergence of sexuality studies since the 1980s has been driven by social constructionist, Foucauldian, queer and feminist studies. ${ }^{4}$ These approaches emerged from post-structuralist and identarian conceptual roots, and focused on the theory and politics of the constitution of identities and subjects. Constructionist approaches focused on the constitution of normativities and discursive practices - constituting sexual

${ }^{2}$ There is considerable material on this case on the web - see selectively: https://www.newstatesman.com/politics/2014/05/comrades-war-decline-and-fall-socialistworkers-party; http://socialistunity.com/swp-party-members-write-full-narrative-comradedelta-rape-case/; https://www.theguardian.com/society/2013/mar/09/socialist-workers-partyrape-kangaroo-court

3 Indicatively: Claes and Reynolds (2013); Duggan (2002); Conrad and Nair (2014).

${ }^{4}$ Selectively across these approaches, see Beasley (2005); Fuss (1991); Jackson and Scott (2010). 
identities, relations, orientations and practices - through institutional pedagogies. ${ }^{5} \mathrm{~A}$ key concern is the way regimes of power/knowledge propagate pathologies, prejudices and oppressions, and their naturalisation and normalisation circulate discursively within the social milieu (Seidman 2010). Foucault's (1976; 1984a; 1984b) historical survey of the construction of sexual subjectivities and normativities and their institutional and political contexts in ancient and Victorian societies is the paradigm study for social constructionist analyses. Mort (2000) extended this analysis to emphasise the centrality of medico-moral discourses in the framing of legal and political regulation in the British case since Victorian times.

Feminist perspectives focused more on the gendered construction of sexuality, where women's subjection and oppression are determinant features of sexual oppression (Jeffreys 1990; 2003; Marinucci 2010). Queer perspectives emphasise the fluidity of the constitution of sexual subjects within the context of a foundational and deconstructive understandings of sexual identity and relations, the performative nature of the reinforcement of gendered and sexual roles and their rupturing by transgression (Butler 1999; Hall et al. 2013; Lovaas, Elia and Yep 2013; Sullivan 2003).

With the exception of feminism, which dates back to Mary Wollstonecraft's (2015/1792) A Vindication of the Rights of Women, these radical approaches date back to the 1960s and the emergence of a visible sexual politics, catalysed by the science of modern sexology in the 1940s and 1950s and the political consequences of the social change after the Second World War.

Much overlooked, socialist and particularly Marxist analyses date back to the late 19th century, with Magnus Hirschfeld's Scientific Humanitarian Committee advocating homosexual and transgender rights (see Weeks 1985) and Eduard Bernstein's defence of same-sex sexuality in commenting on the Oscar Wilde case (Bernstein 1895a; $1895 \mathrm{~b})$. The early years of the Bolshevik revolution saw the initial steps towards an enlightened approach to sexuality, spearheaded by Alexandra Kollontai (Healey 2001; Kollontai 1972; Porter 1980). ${ }^{6}$ Kollontai's thinking prefigured feminist concerns about women's exploitation in social institutions such as marriage and prostitution, but emphasised private property and class inequality and its resulting poverty and immiseration as casual factors in reinforcing gendered inequality and sexual oppression. These early recognitions of sexual politics, whilst underdeveloped, nevertheless show a concern amongst left leaders and intellectuals for sexual issues.

Reynolds (2003) provides an outline of the development of thinking about sexuality within Marxist thought and also seeks to show how Marxist political economy and critiques of hegemony and alienation have been and continue to be effective in challenging the pathology and later recognition and incorporation of sexual politics. In a more personal framing, Fernbach (1981) weaves the narrative of Marxism and homosexuality from Engels (1884) through to the 1980s. The main two strands of interconnection between Marxism and sexual studies between the Bolshevik revolution and the end of the 20th century were in the Freudo-Marxist concerns of the relationship between psyche, sexuality and politics (Robinson 1969) and the focus on family, gender and personal life (Brown 2012; Zaretsky 1976). Both of these are contributory, if sometimes tangential to a critical focus on sexuality within Marxist critiques, with the exception of the marriage of Freud and Marx in Wilhelm Reich and Herbert Marcuse.

${ }^{5}$ The most cogent articulations of this approach are Seidman (2010) (one of the few introductory texts that explicitly addresses Marxism) and Weeks (2016).

${ }^{6}$ For a critical account of the subsequent homophobia in Russia from Stalin to the present day see Healey (2017). 
Though Marxist analyses have become more prominent at the beginning of the 21st century, sexual radicalism has had affinities with political radicalism. Rowbotham and Weeks (1977) look back at the classical sexologists and rehabilitate Edward Carpenter and Havelock Ellis as socialists who move forward, however incrementally, critiques of bourgeois prejudice against non-heterosexual normality at the end of the 19th and beginning of the 20th century. Whilst still within a sexological paradigm, their political momentum significantly contributed to a movement through classic and modern sexology (Alfred Kinsey, William H. Masters, Virginia E. Johnson) to social and cultural critiques of the politics of sexuality. ${ }^{7}$

Likewise, the explosion of sexual politics in the late-1960s and 1970s involved left political movements, influenced by Marxist politics. Robinson (2007) provides a narrative that focuses on the influence of the left on Gay politics in post-war Britain, notably through participation in the Gay Left Collective in the 1960s and early 1970s. The left's participation in sexual politics is a feature of sexual liberation movements across the US and Western Europe, such as the Red Faggots in the Netherlands (indicatively Hekma and Duyvendak 2016; Hekma 2004; Hekma and Giami 2014; Cant and Hemmings 1988; Duberman 2002; Allyn 2001).

Equally, as well as the inspirational politics of Herbert Marcuse (outlined below), Marxist and Marxist-influenced intellectuals developed potent critiques of both the pathologies and prejudices of what Rich (1981) described, from a lesbian-feminist position, as "compulsory heterosexuality". Hocquenghem (1993), for example, provided a potent Freudian influenced Marxist analysis of homophobia and the constitution of homosexuality as a pathologised yet captivating constitutive subject. ${ }^{8}$ This is not the place for a more comprehensive survey of Marxist contributions to the study of sexuality and the trajectories of sexual politics, but this brief sketch underlines the rich contribution, often either diminished or unrecognised, that Marxists have made to the critique of sexual capitalism.

Contemporary Marxist interventions in the theory and politics of sexuality are perhaps less prominently visible as being "Marxist" in character because they seek to develop a critical synergy with feminism, anti-racism, and other critical perspectives. The relationship between feminism and Marxism as "unhappy marriage" (Hartmann 1979) and analysis conjoining sex and class (German 1989) is a long one. More recently, critical engagements with social reproduction theory (Bhattacharya 2017) and intersectionality (Smith 2015; for a general survey, see Taylor, Hines and Casey 2011) underline a desire for an integrated and plurality of left critique within a materialist conception of social life. At the same time, the analysis of sexual capitalism is still one that benefits from a critical political economy of the material instantiation of sexual lives.

\section{A Marxist Analysis of Sexual Capitalism}

A Marxist analysis of sexuality in contemporary societies is based upon a political economy that recognises the crucial - if not singular - drivers of capitalism and class in shaping social relationships and their cultural contexts. It posits a relationship between the development of sexual identities, regimes of legal and political recognition and sexual cultures and normativities, and the development of capitalist markets and hegemonic formations of class domination.

D'Emilio (1992) directly links the emergence of homosexuality as a recognisable sexual identity - apart from a labelling based on particular same-sex practices - with

\footnotetext{
${ }^{7}$ For the best overview of sexology see Bland and Doan (1998a; 1998b).

${ }^{8}$ See also Marshall (1996).
} 
the development of wage labour, the sophistication of which challenges and diversifies the family form. This approach ties identity to the labour process. The way in which capitalism produces identities and identity diversification as the labour process becomes more complex. Mirroring the constructionist deconstruction of sexual identities and pathologies, Red Collective $(1978,8)$ observe the way in which:

[...] perceptions and feelings we have feel natural, human, even eternal, as all capitalist relations do [...] The oppressing structures of monogamy and the various forms of permissiveness within which these personal feelings are felt, make it impossible to become conscious of their specificity (their particularity to this social structure).

Red Collective, developing their critique post-1960s, see the problems with traditional structures of monogamy and permissiveness, as well as sexual identity and its diversification, and tie the constitution of both perceptions and dominant naturalising discourses to the way in which capitalism develops both in commodification and the cultural construction of everyday hegemony. Here, as always, Williams (1977, 112-113) is instructive:

A lived hegemony is always a process. It is not, except analytically, a system or a structure. It is a realised complex of experiences, relationships, and activities, with specific and changing pressures and limits. In practice, that is, hegemony can never be singular. Its internal structures are highly complex, as can readily be seen in any concrete analysis. Moreover (and this is crucial, reminding us of the necessary thrust of the concept), it does not just passively exist as a form of dominance. It has continually to be renewed, recreated, defended and modified. It is also continually resisted, limited, altered, challenged by pressures not at all its own.

A Marxist approach to understanding the operation of the structures and discourses that characterise and constrain sexuality and sexual politics does not see disparate institutional pedagogies and the power/knowledge nexus as key drivers, but as the hegemonising strategies by which class power is retained, consent is manufactured and new opportunities for capitalist markets are produced. This reflects Evans (1993), who focuses on the emergent discourses and legal and political shifts towards sexual citizenship as recognition of particularly lesbian and gay identities. In doing so, he emphasises what becomes a key theme for 21st-century analyses - the hollowness of a sexual politics characterised by the driving force of commodification, where sexual recognition is hand in hand with the emergence of new market opportunities and inclusion is on the basis of consumption. Evans recognises that the commodification of sexual life is prefigurative of a depoliticised and commodified lifestyle that divides sexual identities along class and material lines, leading to an absence of economic rights and weakness and limits to legal, political and social rights within the construction of sexual citizenship. Binnie (1995) and the essays in Gluckman and Reed (1997) extend this analysis of how consumption and commodification defines and characterises the public and cultural space occupied by people of diverse sexualities, diluting the potentiality of the critical extension of a politics rejecting the privatised and personalised politics of sexuality to produce political insights.

This ties in with Herbert Marcuse's $(1969 ; 1998)$ explicit connection of the personal and the political in constructing a radical politics. He rejects Freud's (1957) arguments 
for the need for conformity and repression to civilisation. For Marcuse, the objectification and repressive de-sublimation of the human subject constituted their alienation, and extended to both their valorisation under capitalism as a commodity and their repression from a sense of their sensual lives through technology and the everyday process by which lives were lived as objects and through objects. This limits the sense in which sexual freedom necessarily produces a sensual exploration of self and other, and so dilutes the sense of connecting with others that could constitute a counterhegemonic politics. Marcuse, as with feminists, sees the personal and political as centrally important, but for Marcuse the material determinants of capitalism are central to how both sexual freedom and political freedom are dissipated. ${ }^{9}$

This broad critique of the politics of sexuality under capitalism is reflected in recent Marxist contributions. Lewis (2016) argues for an intersectional radicalism that focuses on the vagaries of capitalism as a central contextualising force. Wolf (2009) reflects a more strident Trotskyist-oriented politics that takes in a range of identity struggles under a Marxist critique of the constitution of post-modern radicalism and its dissolution of class power. Alderson (2016) argues that the constitution of queer politics and contemporary shifts in a more 'tolerant' capitalism mutates radicalism into a politics that sits subversively within parameters that dissipate, and draws from rather than builds opposition to capitalism.

Emphasising the critical importance of materialist political economy, Drucker (2011; 2015) provides a seminal mapping of the relationship between phases of developments in capitalist economies and regimes of accumulation with the social organisation of sexualities in society. With a focus on same-sex identities and relationships, he delineates three regimes of what he describes as "same sex formations", which reflect the cultural and social dominance of particular articulations of same-sex identities in society. He maps these phases as follows: the "invert-dominant" regime existed in the classical imperialist phase of capitalism from the 1870s to the start of the Second World War; the "gay-dominant" regime was part of the Fordist phase of capitalism up until the 1980s; and the "homonormative-dominant" regime started in the neo-liberal phase of capitalism and continues to the present day. The importance of this mapping, which to some extent reflects constructionist characterisations of the emergence of same-sex identity (and other sexual identities such as transgender), from pathology to political contestation through to recognition, is that it attributes strong relationships between how capitalism and class relations develop and how sexual identities and relations develop. There is no easy causal attribution, and there is the question of how mediating variables might delay, defer, suspend or radically change the nature of this relationship.

Drucker recognises that causal attributions theoretically in such a periodisation have to be subordinated to the particular conditions of capitalist development in different regional and national contexts, thus eliding with a materialist analysis that demands that there is a critical analysis focused on the concrete level of class formation, struggle and conflict. Hence there are different forms of both regimes of accumulation and same-sex formations in Europe and North America, Russia and China, Africa, South America and Asia. As Drucker $(2015,60)$ observes:

\footnotetext{
${ }^{9}$ For an interesting contrast of Marcuse with alternative radicals - Foucault and Rubin - see Drucker (2014).
} 
[...] the correspondence between regimes of accumulation and same-sex formations provides evidence for a basic historical materialist assertion: the material relations of production and reproduction constitute the fundamental matrix underlying all of social reality.

One of the strengths of Drucker's framework is to provide a basis for thinking about the forms of same-sex or non-heterosexual identities and relationships that have been legitimated by Fordist and neo-liberal regimes. Here, Drucker distinguishes between "Gay Normality" and "Queer Anti-Capitalism" in reflecting assimilationist positions where sexual identity formation conforms to changing patterns of markets and accumulation regimes, and resistant positions that see in conformity the dissolution of the possibilities of freedom, agency, equality and justice that are central to a sexually free political project. This reflects contemporary critiques of homonormativity and sexual politics. It elides with critical work within sexuality studies, which distinguishes between assimilationist positions (typically reflected in Sullivan 1996) and positions that link sexual recognition with radical politics (such as Conrad and Nair 2014; Gilreath 2011; Sycamore 2008; Warner 1999).

This political critique is important, because it contrasts with a queer politics that is focused on subjective freedom and oriented towards individual and subjective action through a cultural politics. ${ }^{10}$ Klein (2000) advances a cogent materialist critique of queer theory that extends this debate and argues that queer theory offers terms of change that are contingent in their possibilities for social change. The individuation of the queer subject potentially leaves queer politics open to the opportunities offered by neo-liberal capitalism on class grounds and subverts social change through a conservative agenda. In a different vein, Floyd (2009) seeks to find synergies between Marxism and queer politics through a critique that sees their common ground in framing and characterising totality and reification within a dialectic between queer theory and Marxism. The question of how far the conceptual critiques of sexuality are conflicting or potentially in creative tension is still a matter for debate.

This focus on the necessity of a politics of sexuality that has at its core radical social and cultural change has historical resonance in Marxist critiques. Dee (2010), in her analysis of the historical emergence and contemporary politics of LGBT liberation, emphasises the fertile ground of Bolshevik and past socialist engagements with sexual politics, particularly at a global level, as well as the crucial role of the left in connecting identity struggles with class politics and the vagaries of capitalist impoverishment.

Field $(1995,167 ; 172)$ is particularly eloquent in characterising the weakness of identity politics against the importance of a class critique and is worth quoting at length:

The factor which holds all reformist strategies back is the way that they define and ringfence supposedly 'lesbian and gay issues' as though lesbian and gay oppression simply effects those who have same-sex relationships. The reality is that gay oppression is a weapon of social control. We cannot hope to bring about real change for gay people whilst the system which causes gay oppression remains in place. [...] All 'lesbian and gay issues' are rooted in the politics of class struggle. When ambitious, bourgeois 'community leaders' seek to divorce these issues from wider social and political concerns the lesbian and gay movement becomes atrophied. Being able to rework and reassess the reformist gay rights programme in the context of defending working class interests is a vital step in breaking away from the frustrations and divisions of identity politics.

${ }^{10}$ See Butler (1998) and Fraser (1998) for the seminal debate on queer as cultural. 
It enables us to see how the issues which are so close to gay people are of equal importance to the rest of society. Far from losing our identity in this process, we can begin to recognise actual and potential allies all around us. Do we just want the same poverty traps and institutions? Seeking assimilation into what is perceived as 'straight privilege' has led many gay activists to confuse equal rights with equal oppression.

In this short survey, there is not adequate time to do justice to the richness of both historical and contemporary Marxist critiques. It should be apparent, however, that Marxism has become a central and important ground for exploring the vagaries of sexuality under capitalism in all its objectifying, commodifying, alienating and exploitative forms. It is evident that much has changed in the last 60 years with respect to sexual lives. Weeks $(2007,5-6)$, in his personal as well as political and cultural reflections on that change, warns of traps in assessing that change ${ }^{11}$ :

The first is a mindless progressivism that assumes that all is for the best in all possible worlds. The second is a declinist approach, which assumes that all change is for the worst and that the quality of our morality - for which we can read sexual behaviour and values - is in hopeless decline. The third approach assumes continuity: yes, superficial things have changed, but in essence power structures have remained resilient.

Weeks' second and third traps might be attributed to Marxist positions, emphasising the limits to change and emphasising the negative features of this change. It is always important to recognise the changing experience of people under sexual capitalism who have suffered degrees of pathology they might regard as absent or less pronounced. The value of Marxist critiques, however, is their diagnostic power as to how we got to where we are, the continuing limits and problems with where we are, and the real possibilities of emancipation moving forward, where sexual capitalism is challenged by a progressive Marxist (but not simply Marxist) politics.

\section{References}

Alderson, David. 2016. Sex, Needs and Queer Culture: From Liberation to the Post-Gay. London: Zed Books.

Allyn, David. 2001. Make Love, Not War - The Sexual Revolution: An Unfettered History. London: Routledge.

Beasley, Chris. 2005. Gender and Sexuality: Critical Theories, Critical Thinkers. London: Sage.

Bernstein, Eduard. 1895a. On the Occasion of a Sensational Trial. Accessed 27 April, 2018. https://www.marxists.org/reference/archive/bernstein/works/1895/wilde/wilde.htm

Bernstein, Eduard. 1895b. The Judgement of Abnormal Sexual Intercourse. Accessed 27 April, 2018.

https://www.marxists.org/reference/archive/bernstein/works/1895/wilde/homosexual.htm

Bhattacharya, Tithi, ed. 2017. Social Reproduction Theory: Remapping Class, Recentering Oppression. London: Pluto.

Bland, Lucy and Laura Doan, eds. 1998a. Sexology Uncensored: The Documents of Sexual Science. Cambridge: Polity.

Bland, Lucy and Laura Doan, eds. 1998b. Sexology in Culture: Labelling Bodies and Desires. Cambridge: Polity.

${ }^{11}$ See also Weeks and Reynolds (2013) for a discussion of these traps. 
Brown, Heather. 2012. Marx on Gender and the Family: A Critical Study. Leiden: Brill.

Butler. Judith. 1999. Gender Trouble: Feminism and the Subversion of Identity [10th Anniversary edition]. London: Routledge.

Butler, Judith. 1998. Merely Cultural. New Left Review 227: 33-44.

Cant, Bob and Susan Hemming, eds. 1988. Radical Records: Thirty Years of Lesbian and Gay History. London: Routledge.

Claes, Tom and Paul Reynolds. 2013. Why Sexual Ethics and Politics? Why Now? The Journal of the International Network of Sexual Ethics and Politics 1(1): 5-18.

Conrad Ryan and Yasmin Nair, eds. 2014. Against Equality: Queer Revolution Not Mere Inclusion. Edinburgh: AK Press.

D'Emilio, John. 1992. Capitalism and Gay Identity. In Making Trouble: Essays on Gay History, Politics and the University, edited by John D'Emilio, 3-16. New York: Routledge.

Dee, Hannah. 2010. The Red in the Rainbow: Sexuality, Socialism and LGBT Liberation. London: Bookmarks.

Drucker, Peter. 2015. Warped: Gay Normality and Queer Anti-Capitalism. Leiden: Brill.

Drucker, Peter. 2014. Conceptions of sexual Freedom in Marcuse, Foucault and Rubin. The Journal of the International Network of Sexual Ethics and Politics 2 (1): 31-38.

Drucker, Peter. 2011. The Fracturing of LGBT Identities Under Neo-Liberal Capitalism. Historical Materialism: Research in Critical Marxist Theory 19 (4): 3-32.

Duberman, Martin. 2002. Left Out: The Politics of Exclusion: Essays 1964-2002. Cambridge: South End Press.

Duggan, Lisa. 2004. The Twilight of Equality: Neo-Liberalism, Cultural Politics and the Attack on Democracy. Boston, MA: Beacon Press.

Duggan, Lisa. 2002. The New Homonormativity: The Sexual Politics of Neoliberalism. In Materializing Democarcy: Toward a Revitalized Cultural Politics, edited by Russ Castronovo and Dana D. Nelson, 175-194. Durham, NC: Duke University Press.

Edge, Simon. 1995. With Friends Like These: Marxism and Gay Politics. London: Cassell.

Engels, Friedrich. 1884. The Origins of the Family, Private Property and the State. In Marx and Engels Collected Works Volume 26, 129-276. London: Lawrence \& Wishart.

Evans, David. 1993. Sexual Citizenship: The Material Construction of Sexualities. London: Routledge.

Fernbach, David. 1981. The Spiral Path: A Gay Contribution to Human Survival. London: Gay Mens Press.

Field, Nicola. 1995. Over the Rainbow: Money Class Homophobia. London: Pluto Press.

Fischer, Nancy L. and Steven Seidman, eds. 2016. Introducing the New Sexuality Studies [3rd edition]. London: Routledge.

Floyd, Keith, 2009. The Reification of Desire: Towards a Queer Marxism. Minneapolis, MN: Minnesota University Press.

Foucault, Michel. 1984a. The History of Sexuality Volume 2: The Uses of Pleasure. Harmondsworth: Penguin.

Foucault, Michel. 1984b. The History of Sexuality. London: Penguin.

Foucault, Michel. 1976. The History of Sexuality Volume 1: An Introduction. Harmondsworth: Penguin.

Fraser, Nancy. 1998. Heterosexism, Misrecognition and Capitalism: A Response to Judith Butler. New Left Review 228: 140-152.

Freud, Sigmund. 1957. Civilisation and Its Discontents. London: Hogarth Press.

Fuss, Diana, ed. 1991. Inside/Out: Lesbian Theories, Gay Theories. London: Routledge

German, Lindsey. 1989. Sex, Class and Socialism. London: Bookmarks.

Gilreath, Shannon. 2011. The End of Straight Supremacy: Realising Gay Liberation. Cambridge: Cambridge University Press.

Gluckman, Amy and Betsy Reed, eds. 1997. Homo Economics: Capitalism, Community and Lesbian and Gay Life. London: Routledge. 
Hall, Donald E, Anne Marie Jagose, eds; Andrea Bebell and Susan Potter S, contributors. 2013. The Routledge Queer Studies Reader. London: Routledge.

Hartmann, Heidi. 1979. The Unhappy Marriage of Marxism and Feminism: Towards a More Progressive Union. Capital and Class 3 (2): 1-33.

Healey, Dan. 2017. Russian Homophobia from Stalin to Sochi. London: Bloomsbury.

Healey, Dan. 2001. Homosexual Desire in Revolutionary Russia: the Regulation of Sexual and Gender Dissent [2nd edition]. Chicago: Chicago University Press.

Hekma, Gert. 2004. Queer: The Dutch Case. GLQ: A Journal of Lesbian and Gay Studies 10 (2): 276-280.

Hekma, Gert and Jan Willem Duyvendak. 2016. Gay Men and Lesbians in the Netherlands. In Introducing the New Sexuality Studies [3rd edition], edited by Nancy L Fischer and Steven Seidman, 559-563. London: Routledge.

Hekma, Gert and Alain Giami, eds. 2014. Sexual Revolutions. London: Palgrave MacMillan.

Hennessy, Rosemary. 2000. Profit and Pleasure: Sexual Identities in Late Capitalism. London: Routledge.

Hocquenghem, Guy. 1993. Homosexual Desire [2nd edition]. Durham, NC: Duke University Press.

Jackson, Stevi and Sue Scott. 2010. Theorising Sexuality. Maidenhead: Open University Press.

Jeffreys, Sheila. 2003. Unpacking Queer Theory. Cambridge: Polity.

Jeffreys, Sheila. 1990. Anticlimax: A Feminist Perspective on the Sexual Revolution. London: The Women's Press.

Kirsch, Max. 2000. Queer Theory and Social Change. London: Routledge.

Kollontai, Alexandra. 1972. Selected Articles and Speeches. Moscow: Progress.

Lee, Badgett M.V. 2001 Money, Myths and Change: The Economic Lives of Lesbians and Gay Men. Chicago, IL: Chicago University Press.

Lewis, Holly. 2016. The Politics of Everybody: Feminism, Queer Theory and Marxism at the Intersection. London: Zed Books.

Lovaas, Karen, John P. Elia and Gust A. Yep, eds. 2013. LGBT Studies and Queer Theory: New Conflicts, Collaborations, and Contested Terrains. London: Harrington Park Press.

Marinucci, Mimi. 2010. Feminism Is Queer: The Intimate Connection Between Queer and Feminism Theory. London: Zed Books.

Marcuse, Herbert. 1998. Eros and Civilisation: A Philosophical Inquiry into Freud. London: Routledge.

Marcuse, Herbert. 1969. An Essay on Liberation. London: Allan Lane/Penguin.

Marshall, Bill. 1996. Guy Hocquenghem: Beyond Gay Identity. Durham, NC: Duke University Press.

McCreery, Patrick and Kitty Krupat, eds. 1999. Out Front: Lesbians, Gays and the Struggles for Workplace Rights. Social Text 61.

Mort, Frank. 2000. Dangerous Sexualities: Medico-Moral Politics in England since 1830 [2nd edition]. London: Routledge.

Porter, Cathy. 1980. Alexandra Kollontai: A Biography. London: Virago.

Red Collective. 1978. The Politics of Sexuality in Capitalism. London: PDC.

Reiche, Reimut. 1970. Sexuality and Class Struggle. London: New Left Books.

Reynolds, Paul. 2003. Some Thoughts on Marxism and the Social Construction of Sexuality. In Sexualität, Unterschichtenmilieus und Arbeiterlnnenbewegung, edited by Paul Pasteur, Sonja Niederacher and Maria Mesner, 27-37. Leipzig: Akademische Verlagsanstalt.

Rich, Andrienne. 1981. Compulsory Heterosexuality and Lesbian Existence. London: Onlywoman Press.

Robinson, Lucy. 2007. Gay Men and the Left in Post-War Britain: How the Personal Got Political. Manchester: Manchester University Press.

Robinson, Paul A. 1969. The Freudian Left. London: Harper Row. 
Rowbotham, Sheila and Jeffrey Weeks. 1977. Socialism and the New Life: The Personal and Sexual Politics of Edward Carpenter and Havelock Ellis. London: Pluto.

Seidman, Steven. 2010. The Social Construction of Sexuality [2nd edition]. London: W.W. Norton. Second edition.

Simpson, Mark. 1996. Anti-Gay. London: Continuum.

Smith, Sharon. 2015. Women and Socialism: Class, Race and Capital [2nd edition]. Chicago, IL: Haymarket Books.

Sycamore, Mattilda B., ed. 2008. That's Revolting: Queer Strategies for Resisting Assimilation. Berkeley, CA: Soft Skull Press.

Sullivan, Andrew. 1996. Virtually Normal. New York: Vintage.

Taylor, Yvette, Sally Hines and Mark E. Casey, eds. 2011. Theorising Intersectionality and Sexuality. London: Palgrave MacMillan.

Warner, Michael. 1999. The Trouble with Normal: Sex Politics and the Ethics of Queer Life. New York: The Free Press.

Weeks, Jeffrey. 2016. Sexuality [4th edition]. London: Routledge.

Weeks, Jeffrey. 2007. The World We Have Won. London: Routledge

Weeks, Jeffrey and Paul Reynolds. 2013. The World We Have Won? An Interview with Jeffrey Weeks. The Journal of the International Network of Sexual Ethics and Politics 1 (1): 69-84.

Wolf, Sherry. 2009. Sexuality and Socialism: History, Politics and Theory of LGBT Liberation. Chicago, IL: Haymarket Books.

Williams, Raymond. 1977. Marxism and Literature. Oxford: Oxford University Press.

Wollstonecraft, Mary. 2015/1792. A Vindication of the Rights of Women. New York: Vintage.

Zaretsky, Eli. 1976. Capitalism, the Family and Personal Life. London: Pluto.

Zavarzedeh, Mas'ud, Teresa L. Ebert and Donald Morton, eds. 2001. Marxism, Queer Theory, Gender. Book series: Transformation: Marxist Boundary Work in Theory, Economics, Politics and Culture 2. New York: The Red Factory.

\section{About the Author}

Paul Reynolds

Paul Reynolds is Reader in Sociology and Social Philosophy at Edge Hill University. He is a member of the editorial board of Historical Materialism (HM): Research in Critical Marxist Theory and co-editor in chief of the INSEP Sexual Ethics and Politics journal. He co-convenes both INSEP and HM Sexuality and Political Economy Group. He writes on sexuality and radical theory and ethics and most recently has published, with Alison Moore, Childhood and Sexuality: Issues and Controversies (Palgrave; 2017). 